\title{
The Effect of Innovation and Consumer Behavior towards Sustainable Fashion in the Era of Society 5.0 Students of FSR IKJ Product Design
}

\author{
Retno Andri Pamudyarini \\ Art Institutes of Jakarta, Indonesia \\ http://dx.doi.org/10.18415/ijmmu.v8i2.2353
}

\begin{abstract}
Increased innovation in Indonesia has recently encouraged an increase in sustainable fashion in the era of society 5.0 where human and technology synergies can be realized so that society is more prosperous. In addition to innovation, there is consumer behavior, namely mass consumption needs to be reduced so that the production of products in the fashion world can have a long and sustainable life. The research was conducted from January to July 2020 at the Jakarta Arts Institute FSR, Central Jakarta City. The study population was 185 IKJ FSR Product Design students. Sampling in this study used the simple random sampling technique by lottery, while the sample size was 127 using the Slovin formula. The research scoring technique was carried out by determining the score through various questions asked of the respondents by determining the score according to the Likert scale. Methods of data analysis in this study using multiple regression analysis methods with the help of SPSS version 25.0. The findings of this research are (1) Direct influence of process innovation in fashion on sustainable fashion, (2) Direct influence of consumer behavior on sustainable fashion, (3) Direct influence of process innovation in fashion on consumer behavior.
\end{abstract}

Keywords: Process Innovation in Fashion; Consumer Behavior; Sustainable Fashion

\section{Introduction}

The influence of European fashion has occurred to this day and Indonesia has also participated in the flow of fast fashion. Fast fashion is still considered cheap clothing that is produced by retailers (on a small scale) in response to the latest trends, seeking instant profits and shifting rapidly in the face of the latest trends and beyond. This has fostered consumerism in society. However, this condition of fast fashion actually causes piles of waste and carbon emissions that pollute the environment, as well as the exploitation of workers to create cheap products that are accessible to all levels of society. This fast fashion trend is actually an adaptation effort to global trends, where countries that have 4 seasons start a trend of dressing according to the season, and every year it continues to change continuously to become the forerunner of the emergence of fast fashion. Sustainable fashion is a process of changing luxurious fashion products that are integrated with the use of materials from environmentally friendly and renewable resources and are more appreciative of the ethical and social values that consumers and their makers obtain. A sustainable fashion industry should be a pioneer in finding things products that are good, not continuously showing new things as targets. However, we realize that the challenge at present is 
a society that is already dominated by the fast consumption behavior, looking for what is instantaneous and lacking the desire to care (in this case about the environment). Sustainability is in fashion when it is well managed and utilized in a morally responsible manner. To get the results of an assessment of conditions based on field evidence, the researcher decided to research the effect of process innovation and consumer behavior in the global fashion industry and consumer behavior on sustainable fashion among FSR IKJ Product Design students.

The idea that innovation is essential as an effort to build a company's competitiveness, growth and sustainability has been well accepted in various fields. Especially now that various disciplines have used an innovative approach so that the conceptual boundaries of innovation are difficult to distinguish clearly. However, the essence of innovation, according to O'Sullivan and Dooley, is making changes, large and small, radical and incremental, to products, processes, and services that results in the introduction of something new for the organization that adds value to customers and contributes to the knowledge of the organization. Innovation is making changes, both large and small, radical and gradual, to products, processes, and services that result in the introduction of something new to the organization that can add value to customers and contributes to organizational knowledge. From this, we know that something new can be created at any time in all areas of the economy, including fashion. Thus, innovation includes new products or services, new processes, and new organizational structures or new administrative systems. Process innovation in fashion is a gradual change in the way a product or service is created and delivered, which includes improving methods of creation and development, and processes in organizations.

Society 5.0 itself is a "solution" to the 4.0 Industrial Revolution, where many people think that Industry 4.0 will use sophisticated technology machines that will reduce the amount of work done by human labor. Society 5.0 is expected to create new value through the development of advanced technology that can reduce the gap between humans and economic problems in the future. The American Marketing Association in Peter and Olson (2013: 3) defines consumer behavior as the dynamics of the interaction between influence and awareness, behavior, and the environment in which humans exchange aspects of life. According to Kotler and Keller (2012: 173), factors that influence consumer behavior are cultural, social, personal, and psychological. This factor is the basis for determining someone to make a purchase. However, Indonesian culture that is still new to online shopping makes people more inclined to compare it with conventional shopping. The culture of the Indonesian people who are more confident about seeing products directly is a major obstacle for online shopping service providers in this country.

\section{Research Method}

This study's scoring technique was carried out by determining the score through various questions asked of the respondents by determining the score according to the Likert scale. The data analysis method in this research is using multiple regression analysis methods using SPSS version 25.0. This research uses descriptive and verification methods. According to Sugiyono (2012: 11) the descriptive research method is a research conducted to determine the value of the independent variable, either one or more variables without making comparisons or linking one variable to another. Verification research or causality research according to Malhotra (2012: 85) is a study to test the correctness of the causal relationship (causal and effect), which is the relationship between the independent variable (which affects) and the dependent variable (which is influenced). The population in a study needs to be determined so that the research carried out actually gets the data as expected. The population in this study were 185 IKJ FSR Product Design students. In this research, the sampling procedure used the Simple Random Sampling technique by lottery, while the 127 samples were calculated using the Slovin formula. The following is a table of research instruments of the three research variables, namely: 
Table 1. Research Instruments

\begin{tabular}{|l|l|l|l|}
\hline No & Sustainable Fashion Indicator $\left(\mathrm{X}_{1}\right)$ & Innovation Process in Fashion Indicator $\left(\mathrm{X}_{2}\right)$ & $\begin{array}{l}\text { Sustainable Fashion } \\
\text { Indicator }(\mathrm{Y})\end{array}$ \\
\hline 1 & Awareness of environmental impact & Use of new tools and techniques & Identifying needs \\
\hline 2 & $\begin{array}{l}\text { Environmentally friendly product material } \\
\text { responsibility }\end{array}$ & $\begin{array}{l}\text { Configuration of systems and ideas in } \\
\text { the Organization }\end{array}$ & $\begin{array}{l}\text { Search for } \\
\text { products } \\
\text { services }\end{array}$ \\
\hline 3 & Socially responsible fashion workers & $\begin{array}{l}\text { Production results are more effective at lower } \\
\text { costs }\end{array}$ & $\begin{array}{l}\text { Selection of } \\
\text { alternatives }\end{array}$ \\
\hline
\end{tabular}

Validity and Reliability Test

The validity test was carried out to determine the accuracy of the research instrument with each variable consisting of 29 questions. Instruments can measure exactly what to measure. The technique used in calculating the validity is to use the product-moment correlation technique with a significance level of $5 \%$. The results of the validity test show that the $r_{\text {count }}$ value of each question item is greater than the $r_{\text {table }}$ value of 0.444 , so it can be concluded that all the question items in the questionnaire are valid. Reliability test is used to determine whether the research variables can be trusted and relied on. The results showed that the independent variable and the dependent variable had a Cronbach alpha value greater than 0.7, so it could be concluded that the variable was reliable, meaning that the variable was reliable and relatively consistent.

\section{The research hypothesis model can be seen in Figure 1 below:}

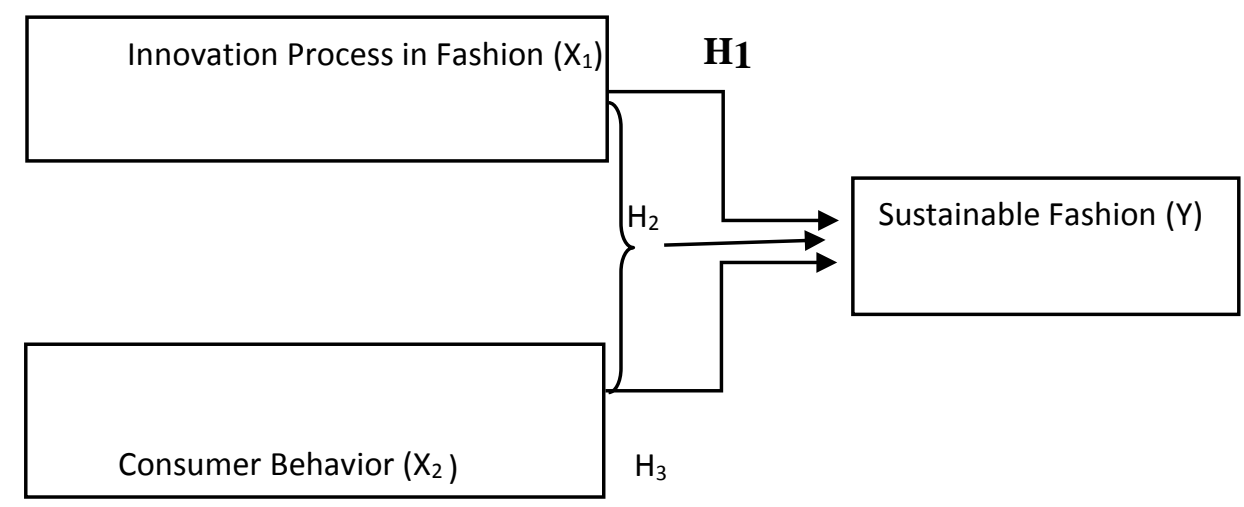

Fig. 1 Model Hipotesis

The formulation of the hypothesis in the study is as follows:

H1: There is a positive and significant influence on variables (X1) innovation process in fashion on sustainable fashion(Y).

$\mathrm{H} 2$ : There is a positive and significant influence on the variable consume behaviour (X2) on sustainable fashion $(\mathrm{Y})$.

H3: There are many positive and significant influences on Information Technology (X3) variables on sustainable fashion (Y). 


\section{Research Result}

The following is a table of statistical descriptions of the three variables:

Descriptive Statistics

\begin{tabular}{ll|l|l} 
& Mean & Std. Deviation & N \\
\hline & & & \\
\hline Sustainable Fashion & 102.85 & 8.668 & 127 \\
\hline $\begin{array}{l}\text { Innovation Process } \\
\text { Fashion }\end{array}$ & 101.04 & 11.602 & 127 \\
\hline \begin{tabular}{l} 
Consumer Behavior \\
\hline
\end{tabular} & 88.04 & 7.987 & 127 \\
\hline
\end{tabular}

SPSS Analysis for Multiple Predictors of Multiple Regression

The regression equation in this study was conducted to determine how much influence the independent variable, namely process innovation $\left(\mathrm{X}_{1}\right)$ and consumer behavior $\left(\mathrm{X}_{2}\right)$, has on the dependent variable, namely sustainable fashion (Y). According to Sugiyono (2012: 275) the simple regression age equation is as follows $\widehat{Y}=\mathrm{a}+b_{1} X_{1}+b_{2} X_{2}$.

\section{Coefficients $^{\mathrm{a}}$}

\begin{tabular}{lllll|l|l} 
Model & & \multicolumn{2}{l}{ Unstandardized Coefficients } \\
B & Std. Error & $\begin{array}{l}\text { Standardized } \\
\text { Coefficients } \\
\text { Beta }\end{array}$ & t & Sig. \\
\hline 1 & (Constant) & 42.653 & 9.606 & & 4.440 & .000 \\
\hline & $\mathrm{X} 1$ & .142 & .059 & .188 & 2.401 & .018 \\
\hline & $\mathrm{X} 2$ & .521 & .085 & .477 & 6.098 & .000 \\
\hline
\end{tabular}

a. Dependent Variable: $Y$

Based on the coefficients above, in column B the constanta $=42,653$, the regression coefficient $b_{1}=0,142$, dan $b_{2}=0,521$. So the multiple regression equation is $\widehat{Y}=42,653+0,142 X_{1}+0,521 X_{2}$.

Hypothesis : $H_{0}: \beta_{1} \leq 0$ vs $H_{1}: \beta_{1}>0$ and $H_{0}: \beta_{2} \leq 0$ vs $H_{1}: \beta_{2}>0$. From the analysis results as summarized in the table shows the statistical price for the $X_{1}$ namely $t_{\text {hit }}=2,401$ and $\mathrm{p}$-value $=$ $0,018 / 2=0,009<0,05$ (right side test), or $H_{0}$ rejected, which means that process innovation has an effect. positive towards sustainable fashion. Furthermore, statistical prices for the coefficient of variable $X_{2}$ namely $t_{\text {count }}=2,644$ and p-value $=0,000 / 2=0,000<0,05$, or $H_{0}$ ejected, which means that consumer behavior has a positive effect on sustainable fashion.

Significance Test of Multiple Regression Equations

ANOVA $^{\mathrm{a}}$

\begin{tabular}{lllllll} 
Model & & Sum of Squares & Df & Mean Square & F & Sig. \\
\hline 1 & Regression & 4349.402 & 2 & 2174.701 & 52.702 & $.000^{\mathrm{b}}$ \\
\cline { 2 - 7 } & Residual & 5116.756 & 124 & 41.264 & & \\
\cline { 2 - 7 } & Total & 9466.157 & 126 & & & \\
\hline
\end{tabular}

a. Dependent Variable: Y

b. Predictors: (Constant), X2, X1

Hypothesis:: $H_{0}: \beta_{1}=\beta_{2}$ or $\beta_{1}-\beta_{2}=0$ and $H_{0}: \beta_{1} \neq \beta_{2}$ or $\beta_{1}-\beta_{2} \neq 0$. rom the analysis results summarized in the table $\mathrm{ANOVA}^{\mathrm{b}}$ it is obtained, $\mathrm{F}_{\text {hit }}=52,702$, or $\mathrm{p}$-value $=0,000<0,05$ or this 
means that $\mathrm{HO}$ is rejected. This means that there is a linear influence on the innovation variable and consumer behavior with sustainable fashion.

Multiple Correlation Coefficient Significance Test

\begin{tabular}{|l|l|l|l|l|l|l|l|l|l|}
\hline \multicolumn{1}{|l|}{ Model Summary } \\
\hline Model & $\mathrm{R}$ & R Square & $\begin{array}{l}\text { Adjusted } \\
\text { Square }\end{array}$ & $\mathrm{R}$ & $\begin{array}{l}\text { Std. Error of } \\
\text { the Estimate }\end{array}$ & $\begin{array}{l}\text { Change Statistics } \\
\text { R Square } \\
\text { Change }\end{array}$ & F Change df1 & df2 & $\begin{array}{l}\text { Sig. } \\
\text { Change }\end{array}$ \\
\hline 1 & $.514^{\mathrm{a}}$ & .264 & .252 & 7.519 & .264 & 21.575 & 2 & 120 & .000 \\
\hline
\end{tabular}

Hypothesis : $H_{0}: \rho_{y .12} \leq 0$ and $H_{1}>0$. Based on the Model Summary table, it can be seen that $F_{\text {hit }}\left(\mathrm{F}_{\text {change }}\right)=21,575$, and $\mathrm{p}$-value $0,000<0,005$ or $\mathrm{H}_{0}$ s rejected. Thus, the multiple correlation coefficients $\mathrm{X}_{1}$ and $\mathrm{X}_{2}$ with $\mathrm{Y}$ are significant or significant.

Significance Test of Partial Correlation Coefficient

The results of the Dependent Variable Normality Test (Y) are as follows:

\begin{tabular}{l}
\hline \multicolumn{5}{|l|}{ Tests of Normality } \\
\hline \multicolumn{4}{|l|l|l|l|l|}{} \\
\end{tabular}

Hypothesis: $H_{0}:$ Normal population distribution, if probability $>0,05, H_{0}$ is accepted and $H_{1}$ : population distribution is not normal, if probability $\leq 0,05, H_{0}$ is rejected. From output table above, for $\mathrm{X}_{1}$ the statistical price for Kolmogorov-Smirnov is 0,057 and $\mathrm{Sig}$ or $\mathrm{p}$-value $=0,200>0,05 \mathrm{H}_{0}$ is accepted, meaning that the continuous fashion population data $(\mathrm{Y})$ is normally distributed. Likewise, the population for variables $\mathrm{X}_{1}$ and $\mathrm{X}_{2}$ are normally distributed.

The formulation of hypothesis is as follows: $\mathrm{H}_{1}=$ there is an influence of process innovation $\left(\mathrm{X}_{1}\right)$ on sustainable fashion $(\mathrm{Y}), \mathrm{H}_{2}=$ there is an influence of consumer behavior $\left(\mathrm{X}_{2}\right)$ on sustainable fashion $(\mathrm{Y})$, and $\mathrm{H}_{3}=$ there is an effect of process innovation $\left(\mathrm{X}_{1}\right)$ and consumer behavior $\left(\mathrm{X}_{2}\right)$ simultaneously towards sustainable fashion $(\mathrm{Y})$. The $t$ test with the basis of decision making is (1) if the value is sig. $<0.05$, or $\mathrm{t}_{\text {count }}>\mathrm{t}_{\text {table }}$, then there is an effect of variable $\mathrm{X}$ on $\mathrm{Y}$, (2) If the value is sig. $>0.05$, or $\mathrm{t}_{\text {count }}<\mathrm{t}_{\text {table }}$, then there is no influence of variable $\mathrm{X}$ on $\mathrm{Y}$.

Table 1. t-test of SPSS Test Results

Coefficients $^{a}$

\begin{tabular}{|c|c|c|c|c|c|}
\hline \multirow[t]{2}{*}{ Model } & \multicolumn{2}{|c|}{ Unstandardized Coefficients } & \multirow{2}{*}{\begin{tabular}{|l} 
Standardized \\
Coefficients \\
Beta \\
\end{tabular}} & \multirow[b]{2}{*}{$\mathrm{T}$} & \multirow[b]{2}{*}{ Sig. } \\
\hline & B & Std. Error & & & \\
\hline (Constant) & 28.689 & 7.433 & & 3.860 & .000 \\
\hline Inovasi Proses & .362 & .050 & .484 & 7.204 & .000 \\
\hline Perilaku Konsumen & .427 & .073 & .394 & 5.865 & .000 \\
\hline
\end{tabular}

a. Dependent Variable: Fashion Berkelanjutan 
Based on the results of SPSS data processing, the value of the value of 7.204 was obtained. The $\mathrm{t}_{\text {table }}$ value is calculated based on $\alpha=5 \%(0.05)$ and $\mathrm{df}=\mathrm{n}-2=127-2=125$, then the $\mathrm{t}$-table value is 2.165. Because the value of $t$ is greater than $t$ table, namely 7.204>2.165 Ho is rejected. This shows the influence of process innovation on sustainable fashion. Manufacturers have a higher desire to innovate to create sustainable fashion in order to maintain consumer satisfaction levels. Based on the table of SPSS test results above, the value of the value is 5.865 . The $t_{\text {table }}$ value is calculated based on $\alpha=5 \%(0.05)$ and $\mathrm{df}=\mathrm{n}-2=127-2=125$, then the $\mathrm{t}_{\text {table }}$ value is 2.165 . Because

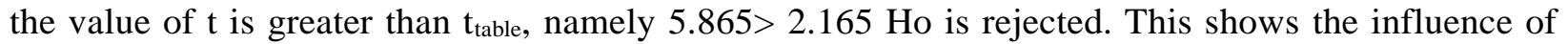
consumer behavior on sustainable fashion.

Here is an $F$ test table, on the basis of decision making as follows: (1) If the sig value $<0.05$, or $\mathrm{F}_{\text {count }}>\mathrm{F}_{\text {table, }}$, then there is an effect of variable $\mathrm{X}$ simultaneously on variable $\mathrm{Y}$, (2) If the sig value $<0.05$, or $\mathrm{F}_{\text {count }}<\mathrm{F}_{\text {table }}$ then there is no effect of variable $\mathrm{X}$ simultaneously on variable $\mathrm{Y}$.

\begin{tabular}{lll|l|l|l|l}
$\begin{array}{l}\text { ANOVA } \\
\text { Model }\end{array}$ & Sum of Squares & df & Mean Square & F & Sig. \\
\hline 1 & Regression & 4349.402 & 2 & 2174.701 & 52.702 & $.000^{\mathrm{b}}$ \\
\cline { 2 - 8 } & Residual & 5116.756 & 124 & 41.264 & & \\
\cline { 2 - 8 } & Total & 9466.157 & 126 & & & \\
\hline
\end{tabular}

a. Dependent Variable: Fashion Berkelanjutan

b. Predictors: (Constant), Perilaku Konsumen, Inovasi Proses

Based on the output above, it is known that the significance value for the effect of $\mathrm{X}_{1}$ and $\mathrm{X}_{2}$ simultaneously on $\mathrm{Y}$ is equal to $0.000<0.05$ and the value of $\mathrm{F}_{\text {count }} 52,702>\mathrm{F}_{\text {table }} 3.07$, meaning that it can be concluded that $\mathrm{H} 3$ is accepted, which means that there is an influence of process innovation and consumer behavior on fashion. sustainable.

\section{Coefficient of Determination}

According to Abdurrahman et al (2011: 218), the coefficient of determination is the square of the correlation coefficient $\left(\mathrm{r}^{2}\right)$ associated with the independent and dependent variables. In regression analysis, the coefficient of determination $(\mathrm{Kd})$ is usually used as the basis for determining the effect of the independent variable on the dependent variable. The formula used is $\mathrm{Kd}=\mathrm{r}^{2} \mathrm{x} 100 \%, \mathrm{Kd}=0$, $459 \mathrm{x} 100 \% \mathrm{Kd}=45.9 \%$. Based on the above calculations the following SPSS.

\begin{tabular}{|c|c|c|c|c|c|}
\hline \multicolumn{6}{|c|}{ Model Summary ${ }^{b}$} \\
\hline Model & $\mathrm{R}$ & R Square & $\begin{array}{l}\text { Adjusted } \\
\text { Square }\end{array}$ & $\mathrm{R}$ & $\begin{array}{l}\text { Std. Error of the } \\
\text { Estimate }\end{array}$ \\
\hline 1 & $.678^{a}$ & .459 & .451 & & 6.424 \\
\hline
\end{tabular}

a. Predictors: (Constant), Perilaku Konsumen, Inovasi Proses

b. Dependent Variable: Fashion Berkelanjutan

Thus, it can be seen that the effect of process innovation and consumer behavior on sustainable fashion is $45.9 \%$ and the remaining $45.1 \%$ is influenced by other factors not examined in this study.

The detailed discussion of the results of the analysis and testing of the research hypothesis is described as follows: 


\begin{tabular}{lll|l|l} 
Correlations & & & \\
& & Inovasi Proses & $\begin{array}{l}\text { Perilaku } \\
\text { Konsumen }\end{array}$ & $\begin{array}{l}\text { Fashion } \\
\text { Berkelanjutan }\end{array}$ \\
\hline \multirow{3}{*}{ Inovasi Proses } & Pearson Correlation & 1 & $.184^{*}$ & $.556^{* * *}$ \\
\cline { 2 - 5 } & Sig. (2-tailed) & & .038 & .000 \\
\cline { 2 - 5 } Perilaku Konsumen & $\mathrm{N}$ & 131 & 127 & 127 \\
\hline \multirow{3}{*}{ Fashion Berkelanjutan } & Pearson Correlation & $.184^{*}$ & 1 & $.483^{* *}$ \\
\cline { 2 - 5 } & Sig. (2-tailed) & .038 & & .000 \\
\cline { 2 - 5 } & $\mathrm{N}$ & 127 & 127 & 127 \\
\cline { 2 - 5 } & Pearson Correlation & $.556^{* *}$ & $.483^{* *}$ & 1 \\
\hline & Sig. (2-tailed) & .000 & .000 & 127 \\
\hline
\end{tabular}

*. Correlation is significant at the 0.05 level (2-tailed).

**. Correlation is significant at the 0.01 level (2-tailed).

\section{Discussion}

1. The Effect of Process Innovation on Sustainable Fashion

From the results of testing the first hypothesis it can be concluded that there is a positive direct effect of process innovation in fashion on sustainable fashion. The results of simple correlation analysis between empowerment and productivity obtained a correlation coefficient of $0.0 .38<0.05$, so collaborating and a path coefficient value of 0.435 . This value implies that process innovation in fashion has an effect on sustainable fashion.

\section{The Influence of Consumer Behavior on Sustainable Fashion}

From the results of testing the second hypothesis it can be concluded that there is a positive direct effect of consumer behavior on sustainable fashion. The results of the simple correlation analysis between consumer behavior and sustainable fashion obtained a correlation coefficient of 0.483 and a path coefficient of 0.316 . This value implies that behavior has a very strong effect on sustainable fashion.

\section{Effect of Process Innovation in Fashion on Consumer Behavior}

From the results of testing the third hypothesis it can be concluded that there is a positive direct effect of process innovation in fashion on consumer behavior. The result of simple correlation analysis between process innovation in fashion and consumer behavior obtained a correlation coefficient of 0.384 and a path coefficient of 0.384 . This value implies that process innovation in fashion has a very strong effect on consumer behavior.

\section{Conclusion}

Based on the results of research data and the results of research data analysis that have been discussed in Chapter IV with all the requirements for data analysis including the estimation error, linearity test and the meaning of the regression has been fulfilled, several conclusions can be drawn as follows: (1) The innovation of the fashion greeting process has a direct effect positive towards sustainable fashion. This means that innovation in the high fashion greeting increase in sustainable fashion, (2) Consumer behavior has a positive direct effect on sustainable fashion. This means that high consumer behavior results in an increase in sustainable fashion, and (3) the innovation of the fashion greeting process has a positive direct effect on consumer behavior. This means that innovation in the high fashion greeting 
process increases consumer behavior. Efforts to Improve Sustainable Fashion through the Innovation of the Salam Fashion Process by paying attention to steps in improving sustainable fashion through innovation in the fashion greeting process can be pursued in various ways. For this reason, it is necessary to explain again that as proposed by the researchers in this study, process innovation in fashion is a gradual change in the way a product or service is made and delivered. In line with sustainable fashion, there needs to be important attention in product development and nuances in the process of changing fashion products that can be integrated with the use of materials from environmentally friendly and renewable resources and respect the ethical and social values obtained by consumers and their makers. This means that it does not only involve business actors and the fashion industry but also consumers to have a new perspective by paying attention to them so that it affects changes in fashion products that are integrated with the use of materials from environmentally friendly and renewable resources as well as more respect for ethical and social values that are obtained by consumers and makers. With various efforts in innovating this fashion greeting process, sustainable fashion improvements can occur. Efforts to improve sustainable fashion can also be done through consumer behavior. Consumer behavior that needs to be considered is how our sustainable fashion ideas and implementation can enter the process of purchasing decision-making processes, as well as in the process when consumers recognize the desire for a product or service that involves searching, selecting alternative purchases, using, and evaluating fashion products.

\section{References}

Aisyah, Edina. (2012). The Influence of Consumer Behavior on Blackberry Purchase Decisions (Case Study at Telkom Institute of Management Dayeuhkolot 2012). Telkom Institute of Management.

Alrasheed, Mishael. (2011). The Impact of Online Consumer Reviews / Ratings on Consumer Behaviors and Their Purchase Decisions. www.brunel.ac.uk/. Brunel University.

Choubtarash, Neshat., Mahdieh, Omid. (2013). The Study of the Relationship Between Consumer Involvement and Purchase Decision (Case Study: Cell Phone). Vol.4 12 April 2013. University of Medical Sciences. Iran.

Khaniwale, Manali. (2015). Consumer Buying Behavior. Vol. 14 No. Apr. 2 2015, pp. 278-286. University of Bridgeport.

Kotler, Philip and Kevin Lane Keller. (2012). Marketing Management, Edition 14, England: Pearson Education.

Maholtra, NareshK. (2012). Marketing Research (Marketing Research) (Edition 4 Volume 1). New Jersey, Indonesia: PT. Index.

Peter, Paul, J., Olson Jerry C. (2013). Consumer Behavior and Marketing Strategy, Edition 9. Jakar t a: Salemba Empat.

Purnama, Rucita. (2013). The Influence of Consumer Behavior on Purchasing Decisions of i Phone in Bandung City in 2012. Telkom University.

Riduwan. (2010). Thesis Preparation Methods and Techniques. Bandung. Alpha-beta.

Sangadji, Sopiah. (2014). Consumer Behavior: A Practical Approach. Yogyakarta: Andi Publisher.

Sugiyono. (2012). Quantitative Research Methods, Qualitative and R \& D. Bandung: Alfabeta.

Suryani, Tatik. (2013). Consumer Behavior in the Internet Age: Implications for Marketing Strategies. Yogyakarta: Graha Ilmu.

Uddin, Md Reaz., Lopa, Nusrat Zahan. (2014). Factors Affecting Customers' Buying Decisions of Mobile Phone: A Study on Khulna City, Bangladesh. Vol. 5, No. 2, June 2014. Khulna University.

Zik Mund, Babin., Car $\mathrm{r} *$ Griff in, (2010). Business Research Methods (8 thed), Canada: South- Western Cengage Learning. https://zalora.co.id access: 6 October 2015. 


\section{Copyrights}

Copyright for this article is retained by the author(s), with first publication rights granted to the journal.

This is an open-access article distributed under the terms and conditions of the Creative Commons Attribution license (http://creativecommons.org/licenses/by/4.0/). 